Article

\title{
The Role of Education in the Prevention of Radicalization and Violent Extremism in Developing Countries
}

\author{
Marlies Sas ${ }^{1, *}$, Koen Ponnet ${ }^{2}\left(\mathbb{D}\right.$, Genserik Reniers ${ }^{3}$ and Wim Hardyns ${ }^{1,4}(\mathbb{D}$ \\ 1 Antwerp Research Group on Safety and Security (ARGoSS) and Research Group on Law Enforcement, \\ University of Antwerp, 2000 Antwerp, Belgium; wim.hardyns@ugent.be \\ 2 Department of Communication Sciences, imec-mict-Ghent University, 9000 Ghent, Belgium; \\ koen.ponnet@ugent.be \\ 3 Antwerp Research Group on Safety and Security (ARGoSS) and Safety and Security Science Group, TUDelft, \\ 2628BL Delft, The Netherlands; G.L.L.M.E.Reniers@tudelft.nl \\ 4 Institute for International Research on Criminal Policy (IRCP), Ghent University, 9000 Ghent, Belgium \\ * Correspondence: marlies.sas@uantwerpen.be
}

Received: 27 February 2020; Accepted: 13 March 2020; Published: 16 March 2020

\begin{abstract}
Only since the beginning of this century, the prevention of radicalization has become an important topic in debates about terrorism and sustainable development in developing countries. Research has shown that radicalized individuals are not uneducated, but have often completed secondary or tertiary education. Additionally, it became clear that some extremist groups consider the school environment as an attractive recruitment place. These findings led to a new approach where the education sector is considered as a prominent partner in preventing and combating the radicalization of young individuals. In this article, the potential limitations of the role of the education sector in developing countries are exposed. Based on previous research, three bottlenecks in the education sector were found: unequal access to education, poor quality of education and the relationship between education and employment. In order to strengthen the role of education for sustainable development in developing countries, it is recommended that equal access to education is improved, that schools invest in the creation of safe spaces for their students, that not only secondary but also primary and tertiary education are involved in policy strategies regarding radicalization, and that the job market is adjusted to the educational level of graduated students.
\end{abstract}

Keywords: radicalization; violent extremism; education; prevention; developing countries

\section{Introduction}

Until two decennia ago, researchers and politicians focused primarily on physical security measures to prevent terrorist-related incidents. Only since the beginning of this century have the concepts of extremism and radicalism occurred more often in debates about terrorism, and increased attention is paid to measures with the aim of preventing individuals from having radical thoughts [1]. After the terrorist attacks in September 2001, the premise grew that a focus on individuals who are actively planning terrorist acts is not enough; it is also necessary to include those people who may anticipate violent crimes in the future in policy strategies.

Until now, the concept of radicalization has not been universally understood in the same way. As studies about radicalization processes were mostly carried out in a conceptual instead of empirical way, there are multiple definitions available, but there still does not exist an unambiguous conceptualization that can be applicable to all individuals or groups. Based on various definitions, Veldhuis and Staun [2] concluded that radicalization can be defined in a broad and narrow context. In a broad way, 
radicalization can be considered as "a social and psychological process of incrementally experienced commitment to extremist political or religious ideology" [3] (p. 152). In a more narrow view, reference can be made to violent radicalization where the use of force is accepted to achieve the indicated goals [2]. By linking radicalization to violent behavior, the concept of violent extremism can be mentioned. Although in literature both terms are often confused, according to Pressman and Flockton [4], they can be considered as a continuum. Individuals can become convinced of radical thoughts that are in conflict with the dominant culture with the aim to cause political, religious or social change, without justifying the use of force. However, it is also possible that people do consider this use of force as a legally accepted way to achieve change, which refers to violent extremism. The boundary between radicalism and violent extremism can be very diffuse as radicalized individuals who do not physically participate in acts of terrorism can play a prominent role in other domains, such as the recruitment or indoctrination of others. With recruitment, we refer to the dynamic process by which a willing or unwilling individual is encouraged or dissuaded from joining a group [5], while during the indoctrination process the individual is inculcated with extremist beliefs [6]. Sieckelinck et al. [7] (p. 330) argued that radicalization can also be described in a pedagogical sense as it "occurs when a child starts to develop political or religious ideas and agency that are fundamentally different from the educational environment's or mainstream's expectations." This focus on the pedagogical aspects led to a renewed interest in the education sector as a prominent partner in preventing and combating the radicalization of individuals [1]. As history shows that education can play a key role in the behavior and beliefs of individuals, it is being seen as one of the main places where radicalization can be prevented from occurring or developing further [8]. This key role of education was first confirmed at the launch of the United Nations Secretary-General's "Plan of Action to Prevent Violent Extremism" in December 2015. This plan focuses on the most necessary preventive measures for individuals who join violent extremist groups. Quality education is seen as one of the ways to address the drivers of radicalization [9]. Additionally, the United Nations Security Council highlighted the role of education in the Resolutions 2178 and 2250, where the need for quality education is emphasized [10,11]. UNESCO's Executive Board published a Decision that underlines the importance of education as a tool to prevent violent extremism and terrorism as well as genocide, racial and religious intolerance, war crimes and crimes against humanity worldwide. It is argued that education is necessary to improve societal commitment processes and to prevent violent extremism, whether it is provided through school systems, clubs and community associations or at home [12].

While currently the majority of research focuses on radicalization in European countries, a growing number of development practitioners are showing interest in the prevention strategies for radicalization in developing countries [1]. The increased attention mainly results from the fact that most terrorism victims have originated in developing countries as the majority of terrorist attacks occurred in only six countries: Iraq, Afghanistan, Nigeria, Syria, Pakistan and Somalia [13]. Additionally, as violence can cause instability, this may have a negative impact on the sustainable development outcomes of terror-related countries [14]. In Tunisia and Egypt, for example, huge declines in tourism and foreign investment have caused a decrease in growth rates [15].

In this article, the role of education in the radicalization of young individuals in developing countries is examined by conducting a literature review. Databases Google Scholar and Web of Science were consulted in search of articles about radicalization, violent extremism and the role of the education sector in developing countries. While defining developing countries is fraught with difficulty, this paper will focus on the categorization of the United Nations, which uses the human development index (HDI) to categorize countries. Based on life expectancy, educational attainment, and adjusted real income, 151 countries can be categorized as developing countries [16]. Only studies focusing on these countries were included in the selection of articles. Searches were conducted during September and October 2019. The most recent publications were searched for, however, no restrictions were made regarding the publishing date of the articles. 
First, the relationship between education and radicalization will be explained according to the educational level of radicalized individuals and the attractiveness of school environments in the recruitment process of extremist groups. Subsequently, three potential limitations of the education sector in developing countries are presented. Based on these findings, recommendations are made for policymakers and researchers who are focusing on the role of education in the prevention of radicalization of young individuals with the aim of sustaining peace and creating sustainable development in developing countries. At the end of the article, a brief conclusion sums up the findings and recommendations.

\section{Relationship between Education and Radicalization}

\subsection{Level of Education of Radicalized Individuals}

Research on radicalization shows that mainly young men between the ages of 15 and 25 are active in the role of offender, a conclusion that seems to be applicable to all regions and cultures worldwide [17]. In Mauritania, for example, young people who were arrested for terrorist-related activities were found between the ages of 16 and 24 [18]. Hutson et al. [19] concluded that in the Middle East, males between 15 and 25 years old are more likely than any other demographic group to engage in terrorism or political violence. In a large part of the literature on Islamic extremism, radicalization is linked to the adolescent phase [7]. According to Silber and Bhatt [6], the radicalization process can be distinguished in four phases: (1) pre-radicalization, (2) self- identification, (3) indoctrination and (4) jihadization. At the first stage, individuals have not been exposed to extremist beliefs and they are leading relatively normal lives. Self-identification refers to individuals' introduction to and eventual embrace of extremist beliefs. During these first two phases, which are observed with individuals between 15 and 35 years old, radical ideas and attitudes are formed. At the third stage, individuals' extremist beliefs intensify and they view violence as necessary to supporting these beliefs. During the fourth stage, the final steps are taken toward violence as the terrorist group or movement's goals take complete precedence for individuals.

The study of Silber and Bhatt [6] also showed that most radicalized people have obtained a degree in secondary or higher education. This is in contrast with the idea that participants of terrorist acts are rather low-skilled. Additionally, Sageman [20] concluded, based on 172 biographies of Salafi-Jihadists that more than $60 \%$ of them have obtained a degree. $88 \%$ of the leaders $(n=25)$ of these groups completed higher studies, of which $20 \%(n=5)$ have obtained a PhD degree. Krueger and Maleckova [21] found in their study that a large majority of terrorists from the Middle East obtained a higher educational degree. The 19 perpetrators involved in the terrorist attacks of 9/11 were also not poorly educated and a large number of Al-Qaeda members appeared to be of middle-class level and received education at university [22]. Osama Bin Laden, the founder of Al-Qaeda, graduated as an engineer and his successor, Ayman Al-Zawahiri, completed a master's degree in surgery. Abu Bakr Al-Baghdadi, the leader of ISIS, had a PhD degree in Islamic theology [23]. The British sociologists Gambetta and Hertog [24] confirmed these findings and concluded in their research that 196 out of 284 examined convicted international terrorists have received higher education, which is a high number in comparison with the average level of education in their countries of origin. The World Bank concluded in a report about Daesh recruitment that the average number of years of education of the recruits exceeds the regional average of their region of origin [25]. In Sub-Saharan Africa, there is a difference of five years of education, while in North Africa and the Middle East, a difference of three years can be observed [26].

However, not every study makes the same conclusions. Gill [27], for example, indicated that there does not exist a clear profile of the demographic characteristics of suicide bombers. The level of education varies from low-skilled to very well-educated offenders. A report prepared by the British House of Commons [28], which was developed after the bombings in London in July 2005, also does not directly link the terrorists' profile with higher education. According to Taşpınar [29], 
mainly uneducated young men from the Casablanca slums were recruited by the Islamic Combatant Group, a Moroccan Jihadist organization. In Sierra Leone and Nigeria, the majority of extremist groups consisted of young individuals who were homeless, unemployed, unmarried and had no education [30]. Kiendrebeogo and Ianchovichina [31] examined the characteristics of radicalized individuals of 27 developing countries and concluded that the typical profile of the radicalized individual is more likely to be a young, uneducated and unemployed individual.

In other studies, a combination of well-educated and less educated participants of violent extremist groups was found. For example, Oyefusi [32] indicated, in his study about rebel groups in the Niger Delta, that often a combination is made between a large number of less educated youth who consider participation as an upgrade in social status and economic opportunities and a smaller group of well-educated individuals who are mainly motivated by political or ideological aspects. In Rwanda, the organizers of the genocide were political elites who were trying to obtain more power, supported by the middle-class who were afraid of a loss of privilege and a large group of poorer and less educated individuals [33].

\subsection{School Environments as Recruitment Places for Extremist Groups}

Terrorist organizations in many places all over the world consider school environments as attractive recruitment places [34]. The Home Affairs Committee [35] refers to three platforms where extremist groups recruit their members: prisons, the internet and the school environment. Over the past two decades, enrollment rates in schools have increased across the developing world [36]. In 2014, globally, $91 \%$ of children enrolled in primary education, while in low and lower middle-income countries, respectively, $81 \%$ and $90 \%$ of children participated. Worldwide, $84 \%$ of children enrolled in lower secondary education in 2014. In low and lower middle-income countries, respectively, $65 \%$ and $80 \%$ of children participated. $63 \%$ of children worldwide enrolled in upper secondary education, which ranged from $40 \%$ in low-income countries to $52 \%$ in lower middle-income countries. The UNESCO Institute for Statistics [37] revealed that in 2016, 215.9 million young people enrolled in higher education. The lowest numbers are found in Central Asia, where 2 million students participated. In Sub-Saharan Africa, 7.4 million youths enrolled, while respectively, 26.2 and 10.8 million students followed higher studies in Latin America and the Arab States. The increased presence of many young individuals in educational systems contributed to the attractiveness of the school environment in recruitment strategies of radical organizations [20].

Additionally, a large number of studies emphasized the opportunities of already existing networks in school environments for recruiters [20,38]. Latif [39], for example, indicated that university campuses in Iraq became central locations for radicalization and recruitment by violent groups. Another example can be found in West Africa during the 1980s, where extremist groups started intensively to provide education, housing, health and employment services in regions with high poverty rates. The Islamic groups used their provision of social services to recruit new members. Especially for young individuals, membership in these radical groups provided them new social statuses with more authority and responsibility and at the same time, the opportunities of housing, employment, marriage and religious education [30].

In Mauritania, recruitment of radicalized youths sometimes occurs in madrasas (Islamic schools) or religious seminaries. In these educational systems, a space for interaction between youth who are prone to violent ideas and those who are not is created. This contrast often leads to more receptiveness of madrasa graduates for ideas of violent extremism [40]. After the breakdown of the Iraqi state in 2003, powerful student groups emerged at the university campuses. In this context of breakdown, the higher educational institutions became ideological battlegrounds and fertile spaces for the recruitment of extremist groups [41]. 


\section{Potential Bottlenecks of the Education Sector in Developing Countries}

\subsection{Limited Access to Education}

As described in the previous sections, there is no coherent view of the relationship between the educational level of young individuals and their radical beliefs or participation in terrorist acts. However, econometric analyses showed that a relationship can be found between countries or regions with low educational levels and their risk of conflict. According to these analyses, unequal access to education often becomes a source of tension, which leads to radicalization, conflict, violence and rebellions [26].

Moser and Rodgers [42] argued that there exists a relationship between violence and unequal access to education, employment, health or basic physical infrastructure. Situations where severe inequality is widespread heighten the potential for frustrated and excluded populations which may lead to an increased number of young individuals participating in different forms of violence. Breidlid [43] argued that deep-rooted grievances about the unequal access to educational systems in Sudan is said to be one of the reasons for the ongoing civil war. In Sierra Leone, the failure of the government to provide qualitative and equal distribution of education for young individuals led many of them to join rebel groups $[44,45]$. The issue of unequal access to education seems to be not only relevant for primary and secondary education, as too often discrimination sneaks in the admission processes for universities. As this was the case for the Tamil youth in Sri Lanka, this provided one of the main impulses for youth to join the military movements in the North during the 1970s [46].

Shafiq and Sinno [47] argued that the relationship between the educational level of a country and the risk of conflict is not straightforward. Political and socioeconomic variables may have a mediating role in this connection. This means that poor political and socioeconomic conditions may increase the chance of terrorist acts, while in favorable conditions, education may further reduce terrorism. Brockhoff et al. [48] concluded, based on an examination of 133 countries over 23 years, that lower educational levels such as primary education lead to more terrorism for a cluster of less socioeconomic and politico-institutional developing countries. Higher levels of education, such as university education, reduce domestic terrorism for a cluster of countries with more favorable conditions [1].

Referring to the well-educated profiles of individuals who participated in recent terrorist attacks, previous research has shown that equal access to education does not per se minimize the risk of radicalization [1]. Mercy Mercy Corps [49] confirmed these findings after carrying out a study to examine the impact of access to formal education on participation and support of political violence of Somali youths. The results show that although the improvement of access to secondary education reduced the participation in political violence by $16 \%$, the support for violence increased with $11 \%$. However, when the improvement of access to secondary education is combined with civic engagement opportunities that allow young individuals to carry out community action campaigns, a decrease of respectively, $14 \%$ and $20 \%$ for participation in and support for political violence is measured. This means that a combination of educational initiatives with civic engagement activities steer youth away from a path towards violence. Therefore, providing education is not enough to prevent radicalization or recruitment of young individuals. Brockhoff et al. [50] argued that equal access to education only has an impact on processes of radicalization when it is combined with a good quality of education.

\subsection{Poor Quality of Education}

Steer et al. [51] argued that while Arab countries invested successfully in equal access to education, the quality is substandard. Based on an analysis of 13 Arab countries, the researchers concluded that $48 \%$ of lower secondary school students fail the basic numeracy and literacy tests. Even students who obtain higher scores, still do not meet the required skills of the $21^{\text {st }}$ century market place. Ladbury and Hussein [52] indicated that the style of education in Pakistan's state schools and madrasas causes raised expectations of young individuals while the lack of skills hinder meeting these hopes in practice. Richards [53] argued that the educational systems in the Middle East, which are often based on rote 
memorization and the obligation to obey the authorities without asking any questions, leave young students vulnerable to extremist narratives.

In this light, Martin-Rayo [54] argued that the quality of education is a determinant factor in the radicalization processes of young individuals. Youths who received even a little quality education are intended to view violence in a more negative way and are less susceptible to ideological brainwashing by radical groups. He refers, in this case, to the Somalis who are living in refugee camps in Kharaz in Yemen. Due to different factors such as language barriers, corrupt payments or violence directed at the Somali students, they experienced institutionalized discrimination in the education system. Upon graduation, some of these students openly showed their interest in joining Al-Qaeda. Agbiboa [55] argued that poor education infrastructure and a lack of dedicated teachers have contributed to the radicalization of many youths in West Africa and the Sahel.

Additionally, the content of the curricula largely influences the quality of education. When during the Cold War, communism and the Soviet Union were considered as the biggest security threats to the West, the United States Agency for International Development (USAID) funded the educational programs in refugee camps in Pakistan and Pakistani madrasas. Between 1984 and 1994, more than 13 million textbooks were distributed among young individuals in Afghan refugee camps and Pakistani madrasas. As these textbooks mainly consisted of hate curriculum focused on the Soviets, this led to the creation of a generation of radicalized youth [56]. In Rwanda, research has shown that the curricula and teaching methods smothered critical thinking, which impacted individuals' responses to the genocide [57]. In 2015, five madrasas in Uganda were closed over allegations that they were educating students to become extremists in favor of a Congolese armed group who were attacking the African Union [58].

Macaluso [1] indicated that the solution to radicalization is not education as such, but the quality of education that is provided. It is important that students learn from other disciplines in order to be open to other opinions, to have intelligent and critical discussions and to understand international and domestic realities. According to Shafiq and Sinno [47], the direct effect of education on radicalization depends on the content of the curricula and the values which are inculcated in the educational institutions.

\subsection{Weak Relationship between Education and the Job Market}

As shown previously, many researchers emphasize the importance of high-quality education, but according to some of them, the relationship between education and the available job market is even more important $[15,46]$. They argue that a combination of quality education, but limited job opportunities, may cause a breeding ground for radicalization. A report of the Combating Terrorism Centre of 2016 revealed that, based on an analysis of 4600 personnel records of Daesh foreign fighters from the Islamic State, most of them were relatively well-educated in comparison to the educational level of their home countries, but most held low-skilled positions [59]. According to Bhatia and Ghanem [15], frustrations over not being able to secure job opportunities in accordance with their level of education could have played a role in the radicalization process. Zaidi [60] indicated that during poor economic times, better educated or qualified individuals are often unemployed which increases the attractiveness of finding simple solutions for complex problems, such as engaging in crime to solve financial problems. If educational attainment raises expectations about employment opportunities that cannot be fulfilled, this can cause a reality-expectation nexus which may create opportunities for extremist groups. ISIS, for example, includes the promise of job opportunities in its recruitment campaign [61]. Research among Sri Lankan youth showed that insufficient employment for well-educated individuals with high aspirations led to strong competition for positions, patronage and disillusionment and unrest. Both the Sinhalese People's Liberation Front and the Tamil Tigers recruited their cadres from the rural youth who were well-educated but frustrated [62]. Today, in countries in the Middle East and North Africa, a university degree rather reduces than increases the 
chance of finding a job. An educated person seems to have no advantages on the job market, but even more disadvantages because his or her expectations cannot be fulfilled [26].

Additionally, in Nigeria, radicalization processes have been enabled by disappointment about employment prospects for many young individuals who had migrated from rural to semi-rural areas with the aim to find a decent job [63]. Under-employment is seen as a major problem for young adults as jobs with little prospect for advancement may be considered as 'dead-end work' and can be a source of embarrassment, social separation and frustration. For example, many young unemployed ex-combatants participated in the riots in Liberia in 2004 [64]. De Jong [65] indicated that the regional uprising in Casamance in Senegal was caused due to youth disaffection and unemployment.

Collier [66] concluded in an econometric study that conflict is most concentrated in countries with low employment rates. According to his analysis, a country will decrease its risk of conflict by four percent when it increases the employment rate with ten percent. According to Brockhoff et al. [67], this makes sense, as countries who are able and willing to provide opportunities and allow those expectations to drive change for the increasingly educated population can turn out positive. In countries or regions who cannot or do not want to respond to the growing level of expectations, the pressure for forced change may build up.

\section{Recommendations for the Education Sector}

The current global security agenda emphasizes on the importance of education in challenging violent extremism and radicalization, and the prevention of participation of young individuals in extremist groups [68]. Unfortunately, there does not exist a perfect 'recipe' to prevent or eradicate radicalization among young individuals. Burde et al. [69] (p. vi) argued that "no robust evidence shows the best ways for education to counter extremism." While some studies show that equal access to education and an improvement of the national levels of educational attainment limits radicalization and the participation of individuals in violent extremism, other researchers are emphasizing on the importance of the quality of education and the availability of job opportunities [70]. However, based on the findings of previous research, some recommendations for the education sector in developing countries can be made. First, policy should provide sufficient resources to improve equal access to education as research has shown that youths who are not in school are at greater risk of radicalization, recruitment into violent groups or participating in criminal events [71,72]. Educational initiatives provide opportunities to create awareness about the recruitment strategies of extremist groups and can stimulate students to think about their future plans [71]. This means that education must become a more attractive platform in comparison to other alternatives, such as involvement in violence. Education should be accessible for everyone and especially for the most marginalized populations [73]. However, it should be questioned whether an improvement of access to education suffices, as we have seen that also well-educated youths participate in violent extremist groups [71].

This brings us to the second recommendation, which is based on the conclusion of Rose [26] (p. 63), who argued that "education itself is not the answer: it needs to be the right sort of education." Many researchers emphasize the importance of the school as a safe space for young individuals where they can explore their ideas freely. Pratchett et al. [74] argued that education can be effective in challenging ideology when it focuses on the allowance for individuals to develop independent thinking and creating space to question and challenge themselves and others. It provides the opportunity to introduce different ideas to young individuals to counter "group think" and possible radical views [59]. As education has the ability to change values and attitudes, this can also contain a negative effect in which school curricula are used as powerful means to mobilize young individuals by exacerbating inequalities or raising unreal expectations. Therefore, it should be the aim of the educational setting to serve as a safe environment where students can find a more inclusive and less rigid expression for their ideals [46]. Osler [75] argued that in this safe learning environment, it must be possible to talk about sensitive political issues and ideals without offending any person or group. Davies [76] (p. 160) described this, as follows: "In safe spaces, turbulence has to be created, in order to investigate how it 
can be resolved—and whether even more or different sorts of turbulence are called for." According to Macaluso [1], critical thinking can function as resistance against the pull factors of radicalization. Therefore, schools should be environments where critical thinking is cultivated, and students are stimulated to ask questions and learn to think beyond taboos and common assumptions. This way, they can transfer their critical thinking skills to other situations outside the school environment.

Third, while at the moment, most attention is paid to secondary schools in developing countries, it is important that also primary and university education are included in the reform strategies [46]. In the Millennium Development Goals, the promise to ensure that all children complete primary school is seen as an essential step towards reducing poverty and achieving sustainability [77]. Linking this to radicalization, Mercer [78] argued that universal access to primary education is of high importance in order to build the necessary resilience among young students [1]. The improvement of personal resilience should lead to better coping strategies for life pressures and challenges and the use of critical thinking skills to appreciate different perspectives [79]. As attitudes and behaviors start to develop during childhood, investment in primary education is needed [1]. Barakat and Milton [80] (p. 1) argued that higher educational institutions "... help shelter and protect an important subset of young men and women during crisis situations, maintaining their hopes in the future, and preventing them from being driven into the hands of violent groups." According to Ozerdem and Jacoby [81], higher education can play a key role in reintegration processes, breaking up armed groups and instituting programs for collecting weapons. For example, research showed that while a large number of university students fought during the war in Libya, the re-opening of the campuses in post-war periods contributed positively towards stability in the country [82]. Opening up universities to critical thinking can contribute to the prevention of radicalization of its students [26].

Finally, as previous research has shown that well-educated persons are more likely to support violent extremism when they are unemployed or underemployed, changes in the education sector should be accompanied by reforms of the job market [15]. This means that the interaction between unemployment and higher education needs more attention. Policymakers should not only focus on education and the supply of labor, but also on the demand for labor. Job markets must be reformed in order to deal with this phenomenon of unemployed but educated young individuals. As education and skills play a key role in securing employment, this can break the cycle in which joining an extremist group is considered as the only viable option [59].

These recommendations should be integrated into the sustainable development processes of developing countries. The potential overlap between the prevention of radicalization and creating sustainable development is especially evident when looking at human security, which includes environmental, economic, health and crime-related threats. The World Bank's 2011 World Development Report [83] indicated that the developmental consequences and human costs of violence are severe and that violence has been the main constraint to create sustainable development. The Frontlines report of the United Nationals Development Programme [16] emphasizes on the central role of youth in the effective and long-term prevention of violent radicalization. It is argued that focusing on young individuals by protecting their rights, fostering their resilience and systematically integrating meaningful participation will serve as a tool for promoting sustainable development and peace.

Finally, it should be mentioned that not only the socioeconomic circumstances of individuals play a role in determining whether they are driven towards extremism by push factors or attracted by pull factors. For each country, community and individual, unique dynamics defy generalizations [84]. According to the United Nations' 2006 Global Counter-Terrorism Strategy [85], these dynamics include a lack of good governance, socioeconomic marginalization, political exclusion, prolonged unresolved conflicts, dehumanization of victims of terrorism, lack of the rule of law and violations of human rights, and ethnic, national and religious discrimination. 


\section{Conclusions}

This article had the aim to examine the role of education in the radicalization processes of young individuals in developing countries. Previous research has shown that the image of the uneducated participant of a violent extremist group does not match with the actual profiles of radicalized youths. It became clear that radical movements do not only recruit low-skilled but also well-educated young individuals. School environments act in these processes often as attractive recruitment places. Based on these findings, the education sector is considered as a prominent partner in the prevention of radicalization and violent extremism. Three potential limitations of the education sector were examined. The unequal access to education, the poor quality of education and the relationship between education and employment were found as potential causes that could increase the vulnerability of youth for radicalization. In order to tackle these limitations, four recommendations were made. Firstly, equal access to education should ensure that going to school is considered as a more viable option in comparison to extremist groups. Secondly, by creating a safe school environment where critical thinking and free exploration of different ideas are stimulated, the vulnerability of students to radicalization can be reduced. Thirdly, changes in the education sector should not only focus on secondary education, but attention should also be paid to primary and university levels. Fourthly, an adaptation of the job market to the educational level of the graduated students is needed in order to prevent frustration of youths which could make them more vulnerable to radicalization. Finally, it should be mentioned that while changes in the education sector can lead to very positive results on the medium term, this should definitely be accompanied by sustainable interventions in other sectors and domains. Current research suggests that there is no universal indicator or determinant of support for or participation in violent extremism. It is considered as a non-linear process that results from a combination of different factors that shape an individual's trajectory [84].

Author Contributions: Conceptualization, M.S.; methodology, M.S.; investigation, M.S.; resources, M.S.; data curation, M.S.; writing—original draft preparation, M.S.; writing-review and editing, K.P., G.R. and W.H.; visualization, M.S.; supervision, K.P., G.R. and W.H.; project administration, M.S., K.P., G.R. and W.H. All authors have read and agreed to the published version of the manuscript.

Funding: This research received no external funding.

Conflicts of Interest: The authors declare no conflict of interest.

\section{References}

1. Macaluso, A. From countering to preventing radicalization through education: Limits and opportunities. Hague Inst. Glob. Justice Work. Pap. 2016, 18, 1-15.

2. Veldhuis, T.; Staun, J. Islamist Radicalisation: A Root Cause Model; Netherlands Institute of International Relations Clingendael The Hague: The Hague, The Netherlands, 2009.

3. Horgan, J. Walking Away from Terrorism: Accounts of Disengagement from Radical and Extremist Movements; Routledge: Abingdon, UK, 2009.

4. Pressman, E.D.; Flockton, J. Calibrating risk for violent political extremists and terrorists: The VERA 2 structured assessment. Br. J. Forensic Pract. 2012, 14, 237-251. [CrossRef]

5. Jones, E. The reception of broadcast terrorism: Recruitment and radicalisation. Int. Rev. Psychiatry 2017, 29, 320-326. [CrossRef] [PubMed]

6. Silber, M.D.; Bhatt, A. Radicalization in the West: The Homegrown Threat; Police Department New York: New York, NY, USA, 2007.

7. Sieckelinck, S.; Kaulingfreks, F.; De Winter, M. Neither villains nor victims: Towards an educational perspective on radicalisation. Br. J. Educ. Stud. 2015, 63, 329-343. [CrossRef]

8. Abbasi, M.A. Towards the de-radicalization of Pakistani society: The need for a balanced and progressive education system. Dialogue 2014, 9, 255-270.

9. United Nations. Plan of Action to Prevent Violent Extremism; United Nationas Global Counter-Terrorism Strategy; United Nations: New York, NY, USA, 2015. 
10. United Nations. Resolution 2178: Threats to International Peace and Security Caused by Terrorist Acts; United Nations: New York, NY, USA, 2014.

11. United Nations. Resolution 2250; United Nations: New York, NY, USA, 2015.

12. UNESCO. Decisions Adopted by the Executive Board at Its 197th Session; UNESCO: Paris, France, 2015.

13. Institute for Economics and Peace. Global Terrorism Index 2018: Measuring the Impact of Terrorism; Institute for Economics and Peace: Sydney, NSW, Australia, 2018.

14. Khan, S.A.R.; Yu, Z. Terrorism in Emerging Economies: A Double-Edged Sword. In Terrorism and Developing Countries; IntechOpen: London, UK, 2019.

15. Bhatia, K.; Ghanem, H. How do Education and Unemployment Affect Support for Violent Extremism; Brookings Global Working Paper Series; Brookings Institution: Washington DC, USA, 2017.

16. United Nations Development Programme. Human Development Report 2019; United Nations: New York, NY, USA, 2019.

17. Schönteich, M. The dangers of youth? Linking offenders, victims and age. Nedcor Iss Crime Index 1999, 3, $22-28$.

18. Boukhars, A. The Drivers of Insecurity in Mauritania; Carnegie Endowment for International Peace: Washington, DC, USA, 2012; Volume 30.

19. Hutson, R.; Long, T.; Page, M. Pathways to violent radicalisation in the Middle East: A model for future studies of transnational Jihad. Rusi J. 2009, 154, 18-26. [CrossRef]

20. Sageman, M. Understanding Terror Networks; University of Pennsylvania Press: Philadelphia, PA, USA, 2004.

21. Krueger, A.B.; Maleckova, J. Education, Poverty, Political Violence and Terrorism: Is There a Causal Connection; National Bureau of Economic Research: Cambridge, MA, USA, 2002.

22. Von Hippel, K. The roots of terrorism: Probing the myths. Political Q. 2002, 73, 25-39. [CrossRef]

23. Zahid, F. Radicalisation of Campuses in Pakistan. Count. Terror. Trends Anal. 2017, 9, 12-15.

24. Gambetta, D.; Hertog, S. Why are there so many Engineers among Islamic Radicals? Eur. J. Sociol. Arch. Eur. De Sociol. 2009, 50, 201-230. [CrossRef]

25. Mak, A. Assessing Aid: What Works, What Doesn't, and Why (A World Bank Policy Research Report). J. Dev. Stud. 1999, 35, 162.

26. Rose, M. Universities and 'radicalisation' in the Middle East and North Africa. J. Secur. Stud. 2017, 19, 49-66.

27. Gill, P. A multi-Dimensional Approach to Suicide Bombing. Int. J. Confl. Violence 2007, 1, 142-159.

28. British House of Commons. Report of the Official Account of the Bombings in London on 7th July 2005; The Stationery Office: London, UK, 2006.

29. Taşpınar, Ö. Fighting Radicalism, not "Terrorism": Root Causes of an International Actor Redefined. Sais Rev. Int. Aff. 2009, 29, 75-86. [CrossRef]

30. Ismail, O. Radicalisation and violent extremism in West Africa: Implications for African and international security. Confl. Secur. Dev. 2013, 13, 209-230. [CrossRef]

31. Kiendrebeogo, Y.; Ianchovichina, E. Who Supports Violent Extremism in Developing Countries? Analysis of Attitudes Based on Value Surveys; The World Bank: Washington, DC, USA, 2016.

32. Oyefusi, A. Oil and the probability of rebel participation among youths in the Niger Delta of Nigeria. J. Peace Res. 2008, 45, 539-555. [CrossRef]

33. Mamdani, M. When Victims Become Killers: Colonialism, Nativism, and the Genocide in Rwanda; Princeton University Press: Princeton, NJ, USA, 2002.

34. Bloom, M. Constructing Expertise: Terrorist Recruitment and "Talent Spotting" in the PIRA, Al Qaeda, and ISIS. Stud. Confl. Terror. 2017, 40, 603-623. [CrossRef]

35. Home Affairs Committee. Roots of Violent Radicalisation; The Stationary Office Limited: London, UK, 2012; Volume 22.

36. UNESCO. Education for People and Planet: Creating Sustainable Futures for All; Global Education Monitoring Report, Ed. United Nations: Paris, France, 2016.

37. UNESCO Institute for Statistics. Data for the Sustainable Development Goals; United Nations: New York, NY, USA, 2016.

38. Snow, D.A.; Zurcher, L.A., Jr.; Ekland-Olson, S. Social networks and social movements: A microstructural approach to differential recruitment. Am. Sociol. Rev. 1980, 45, 787-801. [CrossRef]

39. Latif, A. Democratization and Radicalization in Iraqi Campuses; Iraqi Prospect Organisation: Baghdad, Iraq, 2006.

40. Schmidle, N. The Saharan conundrum. New York Times Mag. 2009, 15. 
41. Krieger, Z. Iraq's Universities Near Collapse. Chron. High. Educ. 2007, 53, A35-A39.

42. Moser, C.; Rodgers, D. Change, Violence and Insecurity in Non-Conflict Situations; Overseas Development Institute: London, UK, 2005.

43. Breidlid, A. Sudanese migrants in the Khartoum area: Fighting for educational space. Int. J. Educ. Dev. 2005, 25, 253-268. [CrossRef]

44. Peters, K.; Richards, P. 'Why we fight': Voices of youth combatants in Sierra Leone. Africa 1998, 68, $183-210$. [CrossRef]

45. Richards, P. The Political Economy of Internal Conflict in Sierra Leone; Clingendael Institute: The Hague, The Netherlands, 2003.

46. Hilker, L.M.; Fraser, E. Youth exclusion, violence, conflict and fragile states. Soc. Dev. Direct 2009, 30, 1-50.

47. Shafiq, N.M.; Sinno, A.H. Education, income, and support for suicide bombings: Evidence from six Muslim countries. J. Confl. Resolut. 2010, 54, 146-178. [CrossRef]

48. Brockhoff, S.; Krieger, T.; Meierriecks, D. Great expectations and hard times: The (nontrivial) impact of education on domestic terrorism. In CESifo Working Paper no. 3817; CESifo Group: Munich, Germany, 2012.

49. Mercy Corps. Critical Choices: Assessing the Effects of Education and Civic Engagement on Somali Youth's Propensity towards Violence; Mercy Corps: Portland, OR, USA, 2016.

50. Brockhoff, S.; Krieger, T.; Meierrieks, D. Ties That do not Bind (Directly): The Education-Terrorism Nexus Revisited; Available at SSRN 1647664; APSA Annual Meeting Paper. 2011.

51. Steer, L.; Ghanem, H.; Jalbout, M. Arab Youth: Missing Educational Foundations for a Productive Life; The Center for Education at the Brookings Institution: Washington, DC, USA, 2014; p. 16.

52. Ladbury, S.; Hussein, M. Developing the Evidence Base for Hypotheses on Extremism and Radicalisation in Pakistan; Independent Report to DFID; DFID: London, UK, April 2008.

53. Richards, A. Socio-Economic Roots of Radicalism? Towards Explaining the Appeal of Islamic Radicals; DIANE Publishing: Collingdale, PA, USA, 2003.

54. Martin-Rayo, F. Countering Radicalization in Refugee Camps: How Education Can Help Defeat AQAP; The Dubai Initiative, Belfer Center for Science and International Affairs, Dubai School of Government (DSG) and the Harvard Kennedy School (HKS): Cambridge, MA, USA, 2011.

55. Agbiboa, D.E. The Nigerian burden: Religious identity, conflict and the current terrorism of Boko Haram. Confl. Secur. Dev. 2013, 13, 1-29. [CrossRef]

56. Novelli, M. Education and countering violent extremism: Western logics from south to north? Comp. A J. Comp. Int. Educ. 2017, 47, 835-851. [CrossRef]

57. Bird, L. Post-Conflict Education: A Review of Literature and CFBY Experience; The Centre for British Teachers: Reading, UK, 2003.

58. Mail Online. Uganda shuts down 5 madrassas over training extremists. Daily Mail, 23 March 2015; 2015.

59. Botha, A.; Abdile, M. Radicalisation and al-Shabaab recruitment in Somalia. Inst. Secur. Stud. Pap. 2014, $2014,20$.

60. Zaidi, S. The poverty-radicalisation nexus in Pakistan. Glob. Crime 2010, 11, 399-420. [CrossRef]

61. Dearden, L. Isis advertises 10 jobs in the 'caliphate' including press officers, bomb makers and teachers. The Independent, 10 April 2015.

62. Peris, V. Two decades after the burning down of the Jaffna library in Sri Lanka. World Socialist Web Site, 30 May 2001.

63. Onuoha, F.C. The islamist challenge: Nigeria's Boko Haram crisis explained. Afr. Secur. Rev. 2010, $19,54-67$. [CrossRef]

64. Sommers, M. Embracing the margins: Working with youth amid war and insecurity. In Too Poor for Peace? Poverty, Conflict and Security in the 21st Century; The Brookings Institution: Washington, DC, USA, 2007.

65. De Jong, F. The Casamance Conflict in Senegal. Report for the Project the Causes of Conflict in the Third World; Netherlands Institute for International Relations Clingendael: The Hague, The Netherlands, 1988.

66. Collier, P. African growth: Why a 'big push'? J. Afr. Econ. 2006, 15, 188-211. [CrossRef]

67. Brockhoff, S.; Krieger, T.; Meierrieks, D. Great expectations and hard times: The (nontrivial) impact of education on domestic terrorism. J. Confl. Resolut. 2015, 59, 1186-1215. [CrossRef]

68. Davies, L. Learning for state-building: Capacity development, education and fragility. Comp. Educ. 2011, 47, 157-180. [CrossRef] 
69. Burde, D.; Guven, O.; Kelcey, J.; Lahmann, H.; Al-Abbadi, K. What Works to Promote Children's Educational Access, Quality of Learning, and Wellbeing in Crisis-Affected Contexts; DFID and INEE: London, UK, 2015.

70. Davies, L. Review of Educational Initiatives in Counter-Extremism Internationally; The Segerstedt Institute: Gothenburg, Sweden, 2018.

71. Davies, L. Security, Extremism and Education: Safeguarding or Surveillance? Br. J. Educ. Stud. 2016, 64, 1-19. [CrossRef]

72. Talbot, C. Education in Conflict Emergencies in Light of the Post-2015 MDGs and EFA Agendas; NORRAG: Geneva, Switzerland, 2013.

73. INEE. The role of Education and Youth in Preventing Urban Violence and Countering Violent Extremism; INEE: Geneva, Switzerland, 2015.

74. Pratchett, L.; Thorp, L.; Wingfield, M.; Lowndes, V.; Jabbar, R. Preventing Support for Violent Extremism through Community Interventions: A Review of the Evidence-Rapid Evidence Assessment Full Final Report; Department for Communities and Local Government: London, UK, 2009.

75. Osler, A. Patriotism, multiculturalism and belonging: Political discourse and the teaching of history. Educ. Rev. 2009, 61, 85-100. [CrossRef]

76. Davies, L. Unsafe Gods: Security, Secularism and Schooling; Institute of Education Press: London, UK, 2014.

77. Ainscow, M.; Miles, S. Making Education for All inclusive: Where next? Prospects 2008, 38, 15-34. [CrossRef]

78. Mercer, M. Universal Access to Education in Gaza; DFID Human Development Resource Center: Cambridge, MA, USA, 2011.

79. Bonnell, J.; Copestake, P.; Kerr, D.; Passy, R.; Reed, C.; Salter, R.; Sarwar, S.; Sheikh, S. Teaching Approaches That Help To Build Resilience to Extremism among Young People; Department for Education (DFE): Research Report DFE-RR119; Department for Education: London, UK, 2011.

80. Barakat, S.; Milton, S. Houses of Wisdom Matter: The Responsibility to Protect and Rebuild Higher Education in the Arab World; Brookings Doha Center: Doha, Qatar, 2015.

81. Ozerdem, A.; Jacoby, T. Post-War Recovery: Disarmament, Demobilization and Reintegration; IB Tauris: London, UK, 2008.

82. Milton, S. The Neglected Pillar of Recovery: A Study of Higher Education in Post-War Iraq and Libya. Ph.D. Thesis, University of York, York, UK, 2013.

83. World Bank. World Development Report; World Bank: Washington, DC, USA, 2011.

84. Fink, N.C.; Bhulai, R. Development and countering violent extremism. In Sustainable Development Goals: The People's Agenda; UNA-UK: London, UK, 2016.

85. General Assembly. UN Global Counter-Terrorism Strategy; United Nations: San Francisco, CA, USA, 2006. 